\title{
Original Article \\ THE EFFECT OF MEMBRANE DIFFUSION POTENTIAL CHANGE ON ANIONIC DRUGS INDOMETHACIN AND BARBITONE INDUCED HUMAN RED BLOOD CELL SHAPE CHANGE AND ON CELLULAR UPTAKE OF DRUGS.
}

AdBR

\author{
NWAFOR A. AND COAKLEY W. T. \\ Department of Human Physiology, Faculty of Basic Medical Sciences, College of Health \\ Sciences, University of Port Harcourt, Nigeria \\ ${ }^{2}$ School of Pure and Applied Biology of Wales College of Cardiff, Cathays Park, Cardiff, U.K. \\ ${ }^{*}$ Author for correspondence
}

\begin{abstract}
The effect of membrane potential change on anionic drugs Indomethacin and barbitone induced human erythrocyte shape change and red cell uptake of drug has been studied using microscopy and spectrophotometry techniques respectively. The membrane potential was changed by reducing the extracellular chloride concentration while maintaining the ionic strength and the osmolarity of the cell suspending solutions constant. At indomethacin and barbitone concentractions necessary to cause marked cell crenation membrane diffusion potential change from - $7.1 \mathrm{mV}$ to 16 . 4niV, led to the reversal of the shape changing properly of the drugs to cup formers. The cellular uptake of drug increased with increasing membrane potential. The membrane potential dependent shape change was also reversible on revering the membrane potential. The results suggest that cellular uptake of drug and drug induced cell shape change was strongly dependent on changes in the extracellular chloride concentration which alter the potential across the erythrocyte membrane. These findings may be of medical significance such as in the design of drugs, for example, for sickle cell diseases, malarial diseases, since knowledge of the concentration and location of the molecules with respect to the membrane surface is required.
\end{abstract}

Key words: Membrane potential anionic drugs, uptake, human erythrocyte.

\section{INTRODUCTION}

Membrane potential is an important characteristic of the biological membrane. Previous studies of cell-drug associations (Mohandas \& Feo, 1975, Kanaho et al 1981; Sheetz and Singer 1974) at membrane potential, E, -7.imV, suggest that membrane potential of the human erythrocytes was not of primary importance in drug membrane interaction. Further studies have linked crenation of erythrocytes with' negatively charged drugs and cup formers with positively changed drugs (Denticke 1969, Fuji et al 1979) for studies carried out at extracellular chloride ion concentration around $145 \mathrm{mM} \mathrm{NaCl}$ (membrane potential, $\mathrm{E}=-7$. ImV). Available evidence in the literature now suggest that correlation exist between membrane diffusion potential and drug membrane interaction (Glaser 1979, 1982, Nwafor and Coakley 1985, 1991). It has been shown that at the drug concentrations necessary to cause marked cell shape changes for cationic drugs (Fuji et at 1979), membrane diffusion potential change influenced the partitioning of the drugs across the membrane (Nwafor and Coakley, 2003). The membrane potential of the human erythrocyte was changed by reducing the extracellular chloride concentration from $-7.1 \mathrm{mV} \quad(145 \mathrm{mM}$ $\mathrm{NaCl})$ to $16.4 \mathrm{mV}(60 \mathrm{mM} \mathrm{NaCl})$ while maintaining the ionic strength and the Osmolarity of the red cell suspending medium constant (Nwafor and Coakley 1991). In the present study we report on membrane potential change effects on 
anionic drugs indomethacin and barbitone (Fujii et al 1979) induced erythrocyte shape change and on cellular uptake of drug according to the standard methods (Nwafor and Coakley, 1986, 1991) from which the contributions that membrane potential make to drug membrane interaction will emerge.

\section{MATERIALS AND METHODS}

The compositions of the erythrocyte suspending solutions of sodium chloride with sorbitol/sodium gluonate buffered with $5 \mathrm{~m} 1 \mathrm{~V} 1$ Hepes at $\mathrm{pH}$ calculated to keep the intracellular chloride ion concentrations and cell volume constant has been described in the accompanying paper and elsewhere (Nwafor and Coakley 1991). In addition, the preparation of the buffered solutions of drugs and the ultraviolet absorption maximum measurement were as described in the accompanying paper (Nwafor and Coakley, in press). The absorption maximum ( $\mathrm{nm})$ for barbitone was 244 and for indomethacine, 320, Microscopy analysis of the samples were as described in the accompany paper and as in previous studies (Nwafor and Coakley 1991, 1985).

\section{RESULTS}

Indomethacin Cells in $60 \mathrm{~m} 1 \mathrm{NaCl} 5 \mathrm{mM}$ Hepes $85 \mathrm{mM}$ Na gluconate $(E=16.4 \mathrm{mV})$ with $5 \mathrm{~mm}$ indomethacin, $\mathrm{pH} 6.94$ internalized membrane. Over $80 \%$ of the cells became stomatcoytes (stage III internalization) within 2 mins of exposure to the drug at both $20^{\circ} \mathrm{C}$ and $37^{\circ} \mathrm{C}$ (Fig. $1)$. The cells maintained a constant shape during a one hour exposure to the drug of the two temperatures. At $\mathrm{E}=$ $7.1 \mathrm{mV}(145 \mathrm{mM} \mathrm{NaCl})$ the cells showed stage III external cells at both $20^{\circ} \mathrm{C}$ and $37^{\circ} \mathrm{C}$ (Fig. 1) in $5 \mathrm{mM}$ indomethacin.

Cells exposed to $1.0 \mathrm{mM}$ indomethacin in $60 \mathrm{mM} \mathrm{NaCl}$ showed a mixture of discocytes and stage I internalized shapes, whereas cells in $145 \mathrm{mM} \mathrm{NaCl}$ with $1.0 \mathrm{mM}$ of the drug showed mixtures of stage I and II externalized shapes consistent with those previously described for cells in $145 \mathrm{mV} \mathrm{NaCl}, \mathrm{pH} 7.32$. Cells in $1.0 \mathrm{ml} 4$ indomethancin did not detectably change their shape during a one hour exposure to the drug at $20^{\circ} \mathrm{C}$ and $37^{\circ} \mathrm{C}$.

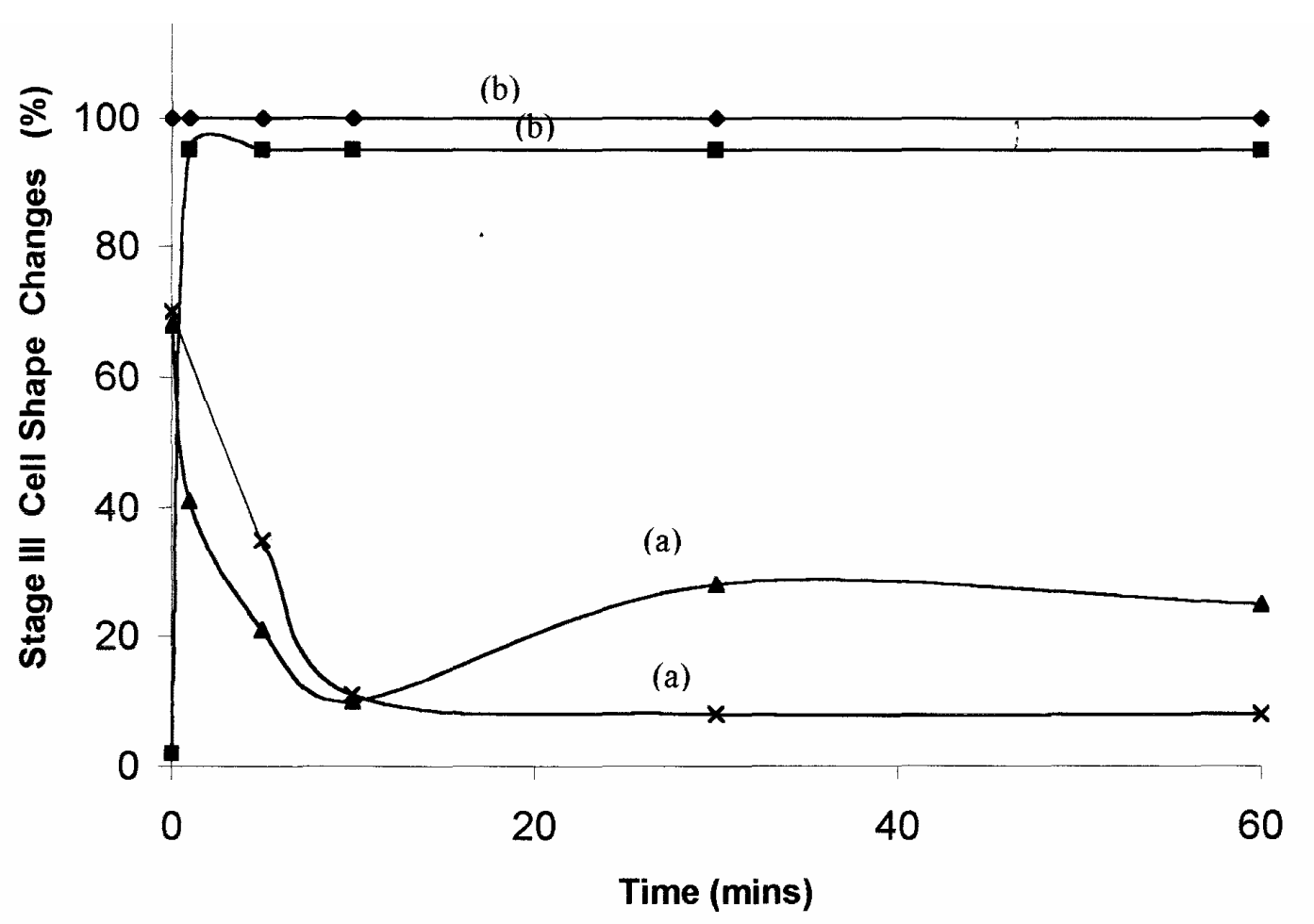

Fig. 1 (a) the incidence of Stage externalized erythrocytes in cell suspensions held in $5 \mathrm{mM}$ indomethacine in $145 \mathrm{mM} \mathrm{NaCl}$ at $20^{\circ} \mathrm{C} \mathrm{(-)}$ and $37^{\circ} \mathrm{C}\left(-^{*}-\right)$. (b) the incidence of stage 111 internalized cells in erythrocyte suspensions maintained in $5 \mathrm{mM}$ indomethacin in $60 \mathrm{mM} \mathrm{NaCl}$ at $20^{\circ} \mathrm{C}$ and $37^{\circ} \mathrm{C}(-\mathrm{U}-)$ for different time. 
Table 1:

Time-dependent shape change of human erythrocytes which have been exposed to $5 \mathrm{mM}$ indornethacin in $60 \mathrm{mM} \mathrm{NaCl} 85 \mathrm{mM} \mathrm{Na}$. Gluconate $5 \mathrm{mM}$ Hepes, Ph 6.94 for 30 mins at $37^{\circ} \mathrm{C}$ and after centrifugation, the cells were resuspended in (a) $145 \mathrm{mIVI} \mathrm{NaCl} 5$ mlvi Hepes with the drug, pH 7.32, and (b) $60 \mathrm{mM} \mathrm{NaCl} 85$ $\mathrm{mM} \mathrm{Na}$ gluconate $5 \mathrm{mlvi}$ Hepes with the drug, $\mathrm{pH} 6.94$, at $37^{\circ} \mathrm{C}$. The results shown are the average of five experiments at each membrane potential.

\begin{tabular}{|l|l|l|l|l|l|l|l|}
\hline & \multicolumn{7}{|c|}{ Time (mins) } \\
\hline$(\%)$ & Stage & 0 & 1 & 2 & 10 & 30 & 60 \\
\hline (a) Echinocyte & III & 0 & 5 & 10 & 15 & 30 & 50 \\
\hline "I & I\&II & 0 & 10 & 15 & 30 & 50 & 40 \\
\hline Discocyte & 0 & 5 & 5 & 10 & 10 & 5 & 10 \\
\hline Stomatocyte & $1 \&$ II & 50 & 55 & 55 & 45 & 15 & 0 \\
\hline “ & III & 45 & 20 & 10 & 0 & 0 & 0 \\
\hline Echinocyte & III & 0 & 0 & 0 & 0 & 0 & 0 \\
\hline “ & I \&II & 0 & 0 & 0 & 0 & 0 & 0 \\
\hline Discocyte & 0 & 0 & 0 & 0 & 0 & 0 & 0 \\
\hline Stomatocyte & I \& II & 0 & 0 & 0 & 0 & 0 & 0 \\
\hline " & III & 100 & 100 & 100 & 80 & 60 & 55 \\
\hline
\end{tabular}

\section{Table 2:}

Time-dependent shape change of human erythrocytes which have been exposed to $5.0 \mathrm{mM}$ indomethacin in $145 \mathrm{mM} \mathrm{NaCl} 5.0$ mlvi Hepes, $\mathrm{pH} 7.32$ for 30 mins at $37^{\circ} \mathrm{C}$ and after centrifugation, the cells were resuspended in (A) $145 \mathrm{mM} \mathrm{NaCl} 5,0 \mathrm{mM}$ Hepes with the drug, $\mathrm{pH} 7.32$, and (B) $60 \mathrm{mM} \mathrm{NaCl} 85 \mathrm{mlvi} \mathrm{Na}$ gluconate $5.0 \mathrm{mM}$ Hepes with the drug, $\mathrm{pH} 6.94$, at $37^{\circ} \mathrm{C}$. The results shown are the average of five experiments at each membrane potential.

\begin{tabular}{|l|l|l|l|l|l|l|l|}
\hline & \multicolumn{7}{|c|}{ Time (mins) } \\
\hline (\% & Stage & 0 & 1 & 2 & 10 & 30 & 60 \\
\hline (a) Echinocyte & III & 2 & 2 & 3 & 10 & 20 & 30 \\
\hline “ & I\&11 & 2 & 2 & 2 & 20 & 55 & 50 \\
\hline Discocyte & 0 & 96 & 96 & 95 & 70 & 25 & 20 \\
\hline Stomatocyte & I \& 11 & 0 & 0 & 0 & 0 & 0 & 0 \\
\hline " & III & 0 & 0 & 0 & 0 & 0 & 0 \\
\hline (a) Echinocyte & III & 0 & 0 & 0 & 0 & 0 & 0 \\
\hline " & I\&II & 0 & 0 & 0 & 0 & 0 & 0 \\
\hline Discocyte & 0 & 0 & 0 & 0 & 10 & 5 & 5 \\
\hline Stomatocyte & I\& II & 85 & 0 & 0 & 40 & 55 & 65 \\
\hline " & III & 15 & 100 & 100 & 50 & 40 & 30 \\
\hline
\end{tabular}

\section{Table 3:}

Time-dependent shape change of human erythrocytes exposed to (a) $120 \mathrm{mM} \mathrm{NaCl} 25 \mathrm{mM} \mathrm{NaCl} 25 \mathrm{mM}$ $\mathrm{Na}$ gluconate $5 \mathrm{mM}$ Hepes with $5 \mathrm{mM}$ indomethacin, $\mathrm{pH} 7.11$, at $37^{\circ} \mathrm{C}$. The results shown are the average of five experiments at each chloride concentration

\begin{tabular}{|l|l|l|l|l|l|}
\hline & \multicolumn{5}{l}{ Time (mins) } \\
\hline$(\%)$ & Stage & 0 & 2 & 30 & 60 \\
\hline (a) Echinocvte & III & 0 & 0 & 5 & 18 \\
\hline “ & I\&II & 30 & 0 & 33 & 40 \\
\hline Discocyte & 0 & 70 & 90 & 62 & 42 \\
\hline Stomatocyte & I \& II & 0 & 10 & 0 & 0 \\
\hline " & III & 0 & 0 & 0 & 0 \\
\hline (a) Echinocyte & III & 0 & 0 & 0 & 0 \\
\hline " & I\&II & 15 & 0 & 0 & 15 \\
\hline Discocvte & 0 & 85 & 100 & 75 & 80 \\
\hline Stomatocyte & I \& II & 85 & 0 & 25 & 2 \\
\hline “ & III & 0 & 0 & 0 & 0 \\
\hline
\end{tabular}

Table 4

The dependent of the shape of human erythrocytes in $5 \mathrm{mM}$ indomethacin, for 30 mins at $37^{\circ} \mathrm{C}$ as a function of both membrane potential and extracellular chloride ion concentration.

\begin{tabular}{|l|l|l|l|l|}
\hline $\begin{array}{l}\text { Sodium chloride } \\
(\mathrm{mM})\end{array}$ & $\begin{array}{l}\text { Membrane } \\
\text { potential (E,mV) }\end{array}$ & $\begin{array}{l}\text { Stage 1+11+111 } \\
\text { Stomatocytic (\%) }\end{array}$ & Biconcave \% & $\begin{array}{c}\text { Stage } \\
1+11+111 \\
\text { Echinocytic }\end{array}$ \\
\hline 145 & -7.14 & 0 & 10 & 90 \\
\hline 120 & -2.08 & 0 & 62 & 38 \\
\hline 90 & 5.60 & 25 & 75 & 0 \\
\hline 60 & 16.43 & 100 & 0 & 0 \\
\hline
\end{tabular}


Tables 1 and 2 show the scores of the morphological changes in erythrocytes exposed to indomethacin sequentially at two membrane potentials. Tables 3 and 4 show the dependence of the shape of erythrocytes in $5 \mathrm{mM}$ indomethacin as a function of extracellular chloride ion concentration and membrane potential. The membrane potential for a maximum in biconcave form after $30 \mathrm{~mm}$ lies between $\mathrm{E}=$ 2. $I \mathrm{mV}$ and $5.6 \mathrm{mV}$. The maximum lies between $E-7.1 \mathrm{lmV}$ and $-2.1 \mathrm{mV}$ for erythrocytes held at $20^{\circ} \mathrm{C}$ for $30 \mathrm{~mm}$ (data not shown). If the initial $(0 \mathrm{~mm})$ change were taken as the most relevant change then table 4 and fig. 1 would place the potential for maximum discocyte forms between $5.6 \mathrm{mV}$ and $16 . \mathrm{mV}$ (probably closer to $5.6 \mathrm{mV}$ ) for cells at $37^{\circ} \mathrm{C}$ in the drugs at the two temperatures. At $E=-7$. imV the cells showed stage III externalized cells at both $20^{\circ} \mathrm{C}$ and $37^{\circ} \mathrm{C}$ in $5 \mathrm{mM}$ indomethacin.

Barbitone: Cells in $60 \mathrm{mM} \mathrm{NaCl}$ with $50 \mathrm{mM}$ barbitone had an initial low incidence of stage III internalized cells at $20^{\circ} \mathrm{C}$ and $37^{\circ} \mathrm{C}$. After 10 mins cells held at $20^{\circ} \mathrm{C}$ slowly grew towards high incidence of stage III stomatocytic shapes with time while cells at $37^{\circ} \mathrm{C}$ retained a low incidence of stage III internalized forms. $\mathrm{pH}$ did not influence the observed effect of membrane potential change on drug induced erythrocyte shape changes. Erythrocytes shape change induced by added drug in low extracellular chloride ion concentration and low extracellular $\mathrm{pH}$. (such as $60 \mathrm{mM} \mathrm{NaCl}, 5 \mathrm{mM}$ Hepes, $85 \mathrm{mM} \mathrm{Na}$ gluconate, $\mathrm{pH} 6.94$ ) was similar to that in low extracellular chloride ion concentration and high extracellular $\mathrm{pH}$ (such as $60 \mathrm{mM} \mathrm{NaCl}, 5 \mathrm{mM}$ Hepes $85 \mathrm{mM} \mathrm{Na}$ gluconate, $\mathrm{pH}$ 7.82). Erythrocytes maintained in $60 \mathrm{mM} \mathrm{NaCl}$ $5 \mathrm{mM}$ Hepes $170 \mathrm{mM}$ sorbitol, $\mathrm{pH} 6.94$ or $\mathrm{pH}$ 7.32, with added drug had similar shape change to those described for cells held in $60 \mathrm{mM} \mathrm{NaCl}$ with gluconate anion, suggesting that extracellular ionic strength and other surface potentials did not influence the shape change.

Table 5: The Influence of Membrane Potential on Drug Membrane Association.

A) The influence of membrane potential on cellular uptake of drugs

B) Shape changes of human erythrocytes induced by drugs in buffered $60 \mathrm{mM} \mathrm{NaCl}$ $5 \mathrm{mM}$ Hepes $85 \mathrm{mM}$ Na gluconate, $\mathrm{pH} 6.94$ at $20^{\circ} \mathrm{C}$ and $37^{\circ} \mathrm{C}$

A

\begin{tabular}{|l|l|l|l|l|}
\hline $\begin{array}{l}\text { Drug/Concentration } \\
(\mathrm{mM})\end{array}$ & Haematocrit & $\begin{array}{l}\text { Cellular uptake (\%) of drug as } \\
\text { function of membrane potential- } \\
7 . \mathrm{ImV} 16.4 \mathrm{Mv} \text { (2. S.E.M) }\end{array}$ & $\begin{array}{l}\text { Ratio of cellular uptake of drug } \\
\text { for a constant erythrocytes in } \\
145 \mathrm{mM} \mathrm{NaCl} \pm 2 \text { S.E.M) }\end{array}$ \\
\hline Indomethacin 5.0 & 4.3 & $25 \pm 0.51$ & $40 \pm 0.25$ & $0.50 \pm 0.18,2.00 \pm 0.18(\mathrm{a})$ \\
\hline Baritone 50 & 4.3 & $21 \pm 0.56$ & $33 \pm 0.23$ & $0.54 \pm 0.18,1.85 \pm 0.18(\mathrm{a})$ \\
\hline
\end{tabular}

$\mathrm{B}$

\begin{tabular}{|l|l|l|l|l|}
\hline $\begin{array}{l}\text { Drug/nature } \\
\text { Concentration } \\
(\mathrm{mM})\end{array}$ & $\begin{array}{l}\text { Type of shape } \\
\text { change induced by } \\
\text { drug in } 6 \mathrm{OnM}-\mathrm{NaCl} \\
\text { at both } 20^{\circ} \mathrm{C} \text { and } \\
37^{\circ} \mathrm{C}(\mathrm{mm})\end{array}$ & $\begin{array}{l}\text { Time } \\
\text { maximum } \\
\text { stage III } \\
\text { shapes at } \\
20^{\circ} \mathrm{C} \text { or } 37^{\circ} \mathrm{C}\end{array}$ & $\begin{array}{l}\text { Change of shape with } \\
\text { temperature increase } \\
\text { after10 mins at constant } \\
\text { drug concentration at } \\
\text { both } 20^{\circ} \mathrm{C} \text { and } 37^{\circ} \mathrm{C}\end{array}$ & $\begin{array}{l}\text { Temperature }\left(20^{\circ} \mathrm{C} \text { or }\right. \\
\text { 370C) at which greater } \\
\text { change from biconcave } \\
\text { fonn was observed after } \\
30 \text { mins maintenance }\end{array}$ \\
\hline $\begin{array}{l}\text { Indomethacin } \\
\text { (anionic drug) } \\
5.0\end{array}$ & Internalization & 0,0 & Away from biconcave & $37 \leq 20$ \\
\hline $\begin{array}{l}\text { Barbitone } \\
\text { (anionic drug) } \\
50\end{array}$ & Internalization & $60, ?$ & Away from biconcave & $20 \geq 37$ \\
\hline
\end{tabular}

? not relevant

(a) the reciprocal of the ratio for the anionic drugs 
Table 5(a) shows the effect of different extracellular chloride concentration on cellular uptake of indomethacin and barbitone. The association of anionic drugs indomethacin and barbitone with erythrocytes at membrane diffusion potential, E, $16.4 \mathrm{mV}$ were greater than was the case for cells at $E=-7.1 \mathrm{mV}$. The partitioning of the negatively charged drugs increased with increasing membrane potential.

The ratio of cellular uptake of drug for a constant extracellular chloride concentration by erythrocytes in $145 \mathrm{mM}$ $\mathrm{NaCl}$ and $60 \mathrm{mM} \mathrm{NaCl}$ for indomethacin and barbitone and haematocrit has the valves given by column 5 of table 5(a). The ratio of the values for the distribution of indomethacine, barbitone across the membrane calculated at $145 \mathrm{mM} \mathrm{NaCl}$ and $60 \mathrm{mM} \mathrm{NaCl}$ at constant haematocrit gave the relative change in interacellular concentration of drug for constant extracellular chloride. The reciprocal of the ratio is also calculated for indomethacine and barbitone. A similar value to the ratio indomethacine was also observed for indomethacine concentration of $0.125 \mathrm{mM}$ below the insoluble concentration rage of the drug.

\section{DISCUSSION}

In the present study at indomethacin and barbitone concentrations necessary to cause marked red blood cell shape change (Fujii et al 1979), membrane diffusion potential change from $E=-7$. ImV to $16.4 \mathrm{mV}$ led to the reversal of the shape changing property of these crenators to cup - formers at both $20^{\circ} \mathrm{C}$ and $37^{\circ} \mathrm{C}$. While cationic drugs on decreasing the extracellular chloride ion concentration led to the reduction of their cup forming property to crenators (Nwafor and Coakley, 2003).

These findings are in contrast to the previous studies in which crenators of erythrocytes have been linked with negatively charge drugs and cup formers with positively charged drugs (Denticke, 1968, Fujii et al 1979) as well as studies of cell - drug associations (Mohandas

and Feo 1975, Kanaho et al 1981) carried out at extracellular chloride concentration of $130 \mathrm{mM} \mathrm{NaCl}(\mathrm{E}=$ $4.2 \mathrm{mV}$ ) and above.

If the distribution of charged drugs across the erythrocyte' membrane is in equilibrium with the distribution, of the chloride ions then.

for cells in $145 \mathrm{mM} \mathrm{NaCl}$,

$\left\{\left[\mathrm{Cl}_{0}^{-}\right]_{145} /\left[\mathrm{Cl}_{\mathrm{i}}^{-}\right]_{145}\right\}=\left[\mathrm{D}_{\mathrm{i}}^{+}\right]_{145} /\left[\mathrm{Cl}^{+}\right]_{145}=\left[\mathrm{D}_{0}^{-}\right]_{145} /\left[\mathrm{D}_{\mathrm{i}}\right]_{145}$

for cells in $60 \mathrm{mM} \mathrm{NaCl}$

$\left\{\left[\mathrm{Cl}^{-}\right]_{60} /\left[\mathrm{Cl}_{\mathrm{i}}\right]_{60}\right\}=\left[\mathrm{D}_{\mathrm{i}}^{+}\right]_{60} /\left[\mathrm{Cl}^{+}\right]_{60}=\left[\mathrm{D}_{0}\right]_{60} /\left[\mathrm{D}_{\mathrm{i}}\right]_{60}$

Since the intracellular chloride ion concentrations were kept constant for cells in either $145 \mathrm{mM} \mathrm{NaCl}$ or $60 \mathrm{mM}$ $\mathrm{NaCl}$, from equations 1.0 and 0.2 we have

$\left\{\left[\mathrm{Cl}_{0}^{-}\right]_{145} /\left[\mathrm{Cl}_{0}\right]_{60}\right\}=\left[\mathrm{D}_{\mathrm{i}}^{+}\right]_{145} /\left[\mathrm{Cl}^{+}\right]_{145} /\left\{\left[\mathrm{D}_{0}^{-}\right]_{60} /\left[\mathrm{D}_{\mathrm{i}}\right]_{60}\right.$ $=\left\{\left[\mathrm{D}_{0}^{-}\right]_{145} /\left[\mathrm{Cl}^{-1}\right]\right\} /\left\{\left[\mathrm{D}_{0}^{-}\right]_{60} /\left[\mathrm{Dl}_{\mathrm{i}}^{-}\right]_{60}\right\}$

For constant haematocrit and constant cell volume the right hand side of equation 3.0 for the positive charged drugs is equal to

$\left[D_{i}\right]_{145} /\left[D_{0}\right]_{145} /\left[D_{i}\right]_{60} /\left[D_{0}\right]_{60}$

and for negatively charged drugs it would be equal to

$$
\left[D_{0}\right]_{145} /\left[D_{i}\right]_{145} /\left[D_{0}\right]_{60} /\left[D_{i}\right]_{60}
$$

The ratios obtained for the influence of membrane potential on cellular uptake of indomethacin and barbitone by the erythrocyte is consistent with the view that membrane potential alter the partitioning of indomethacin and barbitone across the human eiythrocyte membrane in manner which is strongly dependent on the chloride ion distribution, Measurements of amphipath concentration in model and biological membrane using the technique of hygroscopic desorption, suggest that amphipathi molecules are taken up by red cells in such smaller amounts than model membrane (Conrad and Singer 1979, 1981). The binding of the small amphipathic molecules to the lipid phase of erythrocyte membrane has been attributed to some "type of micelle formation between the amphipath from 
the membrane", the mixed micelles being loosely associated with the cell membrane. Recent electron spin resonance (EPR) experiments suggest that amphipathic molecules do probe the hydrophobic regions of both model and biological membranes and do not form micelles on the membrane surface (Moules et al 1982, GafThey et al 983). It is therefore concluded that there is a strong influence of extracellular chloride ion concentration on cellular uptake of drug and drug induced cells shape change. The effect on shape change of altering membrane potential from -7 . $\mathrm{ImV}$ to $16 . \mathrm{mV}$ at $37^{\circ} \mathrm{C}$ was ranked in the order anionic $>$ cationic $>$ neutral drug.

The observation that transmembrane potential can modif the partitioning of drugs tested across the erythrocyte membrane may be of medical significance such as in the design of drugs, for example, for sickle cell diseases, malarial diseases or useful in the design of chemical reagents that interact with biological membrane (such as proble), since a knowledge of the orientation and location of the molecules with respect to the membrane surface is required.

\section{REFERENCES}

Conrad M. J. and Singer S. J. (1981) The solubility of amphipathic molecules in the biological membrane and liquid bilayier and it implications for membrane structure. Biochemistry 20: 508 -818.

Conrad M. J. and Singer S. J. (1979) Evidence for a large internal -pressure in biological membrane. Proc. Matt. Acad. Sci. USA 76: 5202-5206.

B (196Z) Transformation and restoration of biconcave shape of human ei31 induced by amphiphilic agents and changes of ionic environment. fisodicin. Biophys. Ada 163: 44500.

Fujl, T; Sato, T; Tamuru, A; Wakatsuki, M; Kanaho Y. (1979) Shape changes of human ef)Throcytes induced by various amphiphatic drugs on membrane of the intact cells Biochem. Pharmacol. 28: 6 13-620.

GaffleyB. J Willingham, G. L. and Schepp. R. S. (1983) Biochemistry, 22:88'1-892.

Qlasei- R (1982) Echinocytic formation induced by potential changes of human red cells, J. Membrane Biol 66: 70-85

Glaser R. (1979) The shape of Red blood cells as a function of membrane potential and temperature J. Membrane Biol S I 21 7-228.

Kanaho V. Sato T. and Fujii T. (198 I). The affinity of various phenothiozine drugs for Ihembrane of intact human erythrocytes aiid their membrane transfonning activity. Pham. 20: 704-708.

Mohandas N and Feo C. (1975) A quantitative study of the red cell shape changes, produced by anionic and cationic derivatives of phenothiazine. Blood cell 1 375- 384.

Mouls I. K.: Rooney E. K. and Lec L.G. (1Q81) MFebs Lett. 138; 95-100.

Nwafor A. and Coakley IV. T. (2003): Membrane potential effects on cationic drugs chlorpromazine and tetracaine and neutral drug benzy alcohol induced erytlirocyte shape change and cellular uptake of drug. Afr. J. Biomed. Res. 6 (1):

Nwafor A. and Coakley W. 1. (1985) Drug induced shape in erythrocytes correlates with membrane potential change and is independent of glycocalyx. Biochem. Pharm 3'l 3328-3336.

Nwafor A. and Coakley W. 1. (1981). The effect of elevated temperature on drug and transmembrane potential change on the fragmentation of human red blood cells $\mathrm{N} \mathrm{J}$. Physiol Sci. 7:8-II. 